\title{
Participation in interdisciplinary meetings on genetic diagnostics (NGS)
}

\author{
Tom Koole ${ }^{\star, 1,2}$, Lotte van Burgsteden ${ }^{1}$, Paulien Harms ${ }^{1}$, 5GPM-team ${ }^{3}$, Cleo C van Diemen ${ }^{3}$ and \\ Irene $M$ van Langen ${ }^{3}$
}

Diagnostics using next generation sequencing (NGS) requires high-quality interdisciplinary collaboration. In order to gain insight into this crucial collaborative process, we made video recordings of a new multidisciplinary team at work in the clinical genetics department of the University Medical Centre Groningen. Conversation Analysis was used to investigate the ways in which the team members deal with the disciplinary boundaries between them. We found that the team established different "participation frames' in which to discuss recurring topics. Patients were discussed only by the medical doctors, whereas results of genetic tests were discussed by doctors, molecular biologists and genetic laboratory technicians. Information technology (IT) aspects were discussed by biologists, genetics analysts and bio-informaticians, but not doctors. We then interviewed team members who said they believed that the division of labour embodied in these participation frames contributes to achieving their team's goals.

European Journal of Human Genetics (2017) 25, 1099-1105; doi:10.1038/ejhg.2017.111; published online 23 August 2017

\section{INTRODUCTION}

New techniques in genetics like whole exome sequencing (WES) and whole genome sequencing (WGS) enable fast, accurate and relatively cheap genome diagnostic procedures to be performed in critical medical situations. In 2014 the Department of Genetics of the University Medical Centre Groningen established the ' 5 genes per minute' (5GPM) project to implement these developments in diagnosing critically ill newborns. There were two goals: to reach a rapid diagnosis of newborns with a suspected genetic disease and to develop a pipeline of genetic analysis tools to support these diagnoses. The team meets for $1 \mathrm{~h}$ a week to discuss new patients, the results of the genetic analyses, and possible improvements and additions to the analysis pipeline. The team consists of clinical geneticists, paediatricians, molecular geneticists, laboratory staff, and of bioinformaticians. It is supported by an ethics and legal advisory board that includes a patient representative to consider incidental findings.

From the start the team were well aware that its composition could have communication consequences. The team was an unusual mix and each discipline was expected to use its own professional jargon which would only be partially understood by the other team members. The team members faced problems of how to make themselves understood to and how to understand other group members from other disciplines. This is not a unique situation, since many professionals around the world are trying to set up clinically useful pipelines for WES and WGS, mostly in a multidisciplinary setting. Research on such a team's communication strategies can therefore be useful for the genetics community as a whole.

The 5GPM team invited the Humanities Faculty, University of Groningen, to observe and analyse their communication and make recommendations on how they could best communicate with each other. This study is part of a research line into interdisciplinary collaboration and communication, primarily in a medical context. Review articles on interdisciplinary meetings such as Bokhour ${ }^{1}$ and Youngwerth and Twaddle $^{2}$ have been published in medical journals and deal with studies in a medical context while, in contrast, the recent Cambridge Handbook of Meeting Science ${ }^{3}$ which has contributions from a range of meeting researchers does not cover interdisciplinary meetings at all. Interdisciplinary meetings are increasingly common in the medical world and are recognised as presenting potential communication problems, thus making their communication strategies worth investigating.

Research to date has aimed to identify the factors that contribute to successful interdisciplinary communication, ${ }^{4}$ to establish the effects of specific interventions and tools in this setting, ${ }^{5}$ and to discover how participants in interdisciplinary meetings bring about what is called 'collective communicative competence'. 6 Unfortunately, factors that would contribute to successful interdisciplinary meetings, such as 'collaboration', 'coordination', 'pooling of resources', 'individual learning' and 'role blurring', 4 are only formulated at a general level which does not always allow participants in such interdisciplinary meetings to use them as guidelines.

Our observational study was interested in how the participants of the 5GPM project group bring about their meetings as an interactional achievement. ${ }^{7}$ In particular, we discovered that the team did not develop a common terminology, but instead established different participation frames, ${ }^{8}$ in which different subsets of team members discuss different aspects of their work.

Goffman introduced the concept of participation frames ${ }^{8}$ and divided the notions of speaker and listener into a typology that recognises different ways in which a participant can be a speaker or a

\footnotetext{
${ }^{1}$ Communication and Information Sciences, University of Groningen, Groningen, The Netherlands; ${ }^{2}$ School of Human and Community Development, University of the Witwatersrand, Johannesburg, South Africa; ${ }^{3}$ Department of Genetics, University Medical Centre Groningen, Groningen, The Netherlands

${ }^{*}$ Correspondence: Professor T Koole, Communication and Information Sciences, University of Groningen, PO Box 716, Groningen 9700 AS, The Netherlands.

Tel: +31 50 3638548; Fax: +3150 3634900; E-mail: tom.koole@rug.nl

Received 5 December 2016; revised 27 March 2017; accepted 13 June 2017; published online 23 August 2017
} 
listener. ${ }^{9}$ The different listener roles were particularly relevant in our study. Following Goffman ${ }^{9}$ we distinguished between the addressee to whom talk is directly addressed and the ratified overhearer who is known and allowed to listen but who is not the primary recipient of the talk. In the course of a social gathering such as a meeting, the participation frame may change as participants change roles from speaker to addressee, to overhearer and back again.

We identified the interactional practices that were used to accomplish these participation frames such as the use of technical vocabulary, medical reasoning, joking and embodied practices ${ }^{10}$ such as head nods and gaze. ${ }^{1-13}$ We have also assessed how far these practices and the resulting participation frames enable the 5GPM team to achieve their goals. Based on our observations, we can now make some suggestions for other groups aiming to set up interdisciplinary meetings in the context of next generation sequencing (NGS) diagnostics.

\section{MATERIALS AND METHODS}

In order to produce a descriptive analysis of the communication in this team, we video-recorded the weekly meetings in which new patients were introduced, analyses of genetic tests were shown, diagnostic work and the clinical consequences were discussed, and in which the efficiency and further development of the 5GPM-pipeline was discussed. We recorded seven consecutive 1-h meetings (420 min total) over a period of 2 months. We used three video cameras to capture the talk and body movement of all participants during the meetings. In total, 23 individuals participated in the meetings. All participants spoke Dutch. Table 1 shows the pseudonyms of the participants described in the data extracts below and their respective fields of expertise.

For our analysis the video-recordings were synchronised and viewed on one screen in order to allow us to see all simultaneous activity in one view. A selection was made of all activities in which the team discussed either patients, genetic testing or the analysis pipeline, resulting in $210 \mathrm{~min}$ of video data. These were transcribed according to Conversation-Analytical (CA) transcription conventions. ${ }^{14}$ Transcripts capture the verbal and bodily behaviour, including details like hesitations, silences, overlapping talk, intonation, head nods and gaze direction. This produces a version of the interaction that allows the analyst to spend more time on the details of an interactional process than the real-time of its actual duration. Transcripts are a methodological means that allows the detailed analysis of video-data, but they are not data in themselves. The true data is the video which means that an analysis of the transcript goes hand in hand with multiple viewings of the video.

The 210 min of video data were analysed using CA methods. CA is a theory of talk-in-interaction and offers a qualitative method for its investigation that aims to explore the methods that participants in interaction use to conduct their interactional activities. ${ }^{15}$ These include methods for making an utterance

Table 1 Pseudonyms of team members and their expertise

\begin{tabular}{ll}
\hline Pseudonym $(a-z)$ & Expertise \\
\hline Bob & Bio-informatician \\
Ben & Bio-informatician \\
Cara & Clinical geneticist \\
Cindy & Clinical geneticist \\
Carol & Clinical geneticist \\
Chris & Clinical geneticist \\
Mary & Molecular geneticist \\
Mike & Molecular geneticist \\
Pat & Paediatrician/Neonatologist \\
Tim & Genetics technician \\
Tracy & Genetics technician \\
\hline
\end{tabular}

recognisable as a particular action, ${ }^{16}$ for talking in turns ${ }^{17,18}$ and for conducting activities such as giving explanations or making joint decisions. ${ }^{19}$ In this study, we focused particularly on the methods speakers used for selecting recipients, the methods listeners used to display recipiency, and on the resulting participation frames. After having established three different frames we performed the CA method of 'deviant case analysis' ${ }^{20}$ but did not come across cases in our data where 'unexpected' participants made a failed attempt to enter a discussion.

After finishing our CA, we presented the results to the 5GPM team and then interviewed team members from all the different disciplines so that we could gauge their views on whether the resulting participation frames contribute to successful interdisciplinary collaboration.

It is important to note that no patient details were recorded on video and that no personal details of patients or their parents were discussed during meetings. A numerical ID was used for each patient during the discussions. The 5GPM project was approved by the UMCG ethics review board (no. 2014092). All team members signed an informed consent form.

\section{RESULTS}

In general our data analysis showed that the team members present made up different participation frames during the course of a meeting, related to the topics under discussion. The general picture that emerged showed three primary formats:

(i) Discussions of patients were conducted almost exclusively by medical doctors (clinical geneticists and paediatricians), both in terms of selecting addressees and in terms of self-selecting as addressees;

(ii) Discussions of the results of genetic tests were conducted by medical doctors, molecular geneticists and laboratory staff, with the exclusion of bio-informaticians;

(iii) Discussions of the information technology (IT) aspects of genetic testing were conducted by bio-informaticians, molecular geneticists and lab technicians.

What follows below is a demonstration of these different communication strategies using examples from the transcripts.

\section{(i) The patient-discussion-frame}

Meeting 2 had 14 participants, but when one of them introduced a new patient only a few, medically trained members participated in this report.

Vocabulary. One means by which a speaker can select an audience and exclude others is in their choice of vocabulary. For example when paediatrician/neonatologist Pat introduced a new patient she made extensive use of medical terminology, which works to include some participants while excluding others (Box 1).

\section{Box 1 Transcription conventions}

\begin{tabular}{ll}
\hline$:$ & simultaneous verbal and physical activity \\
{$[:$} & simultaneous verbal activities \\
${ }^{\circ}:$ & softer than surrounding talk \\
LANG: & louder than surrounding talk \\
$\uparrow$ dan: & rising syllable intonation \\
wij: & stressed syllable \\
$():$. & pause shorter than $0.3 \mathrm{~s}$ \\
$($ ): & speech not understood \\
$(1.0):$ & pause of $1.0 \mathrm{~s}$ \\
$>$ Joke: & gazes at Joke \\
$\uparrow \downarrow:$ & nods: up and down
\end{tabular}


(1) Meeting 2: 0028-0113

\begin{tabular}{|c|c|c|}
\hline 1 & Pat: & $\begin{array}{l}\text { \{Als wij kijken naar die hersenbloeding } \\
\text { When we look at this brain haemorrhage }\end{array}$ \\
\hline 2 & & $\{>$ at nobody in particular \\
\hline 3 & & $\begin{array}{l}\text { dan zeggen we het ziet eruit } \\
\text { then we say it looks }\end{array}$ \\
\hline 4 & & $\begin{array}{l}\text { als een germi\{nale laagbloeding } \\
\text { like a germinal haemorrhage }\end{array}$ \\
\hline 5 & & $\{>$ Cindy \\
\hline 6 & & $\begin{array}{l}\text { (.) groot (.) } \text { met een hemorrhagisch (.) infarct, } \\
\text { (.) large (.) with a haemorrhagic (.) infarct, }\end{array}$ \\
\hline 7 & & $\{>$ paper \\
\hline 8 & & $>$ Cindy \\
\hline 9 & & $\begin{array}{l}\text { 'dat zien we eigenlijk bij prema \{turen } \\
\text { 'we see that actually in premature infants }\end{array}$ \\
\hline 10 & Carol: & $\{\uparrow \downarrow \uparrow \downarrow$ \\
\hline 11 & Pat: & $\begin{array}{l}\text { en (.) eigenlijk niet zo }\{\mathrm{bij} \\
\text { and (.) actually not really with }\end{array}$ \\
\hline 12 & & $\{>$ Carol \\
\hline 13 & & $\begin{array}{l}\text { (.) à terme kinderen } \\
\text { (.) at term newborns }\end{array}$ \\
\hline
\end{tabular}

In this extract, Pat talks about a 'germinal haemorrhage', a 'haemorrhagic infarct', 'premature infants' and 'at term newborns'. Later she lists the medication the child was given as 'phenobarbital, lidocaine, midazolam, levetiracetam, vigabatrin, pyridoxine, pyridoxalphosphate and folic acid'. These are all medical and pharmaceutical terms that are not necessarily familiar to the entire team present and thus the use of this terminology works to select the medical staff, who were 5 of the 13 other participants in the meeting, as a primary audience.

That the use of specific terminology works to select recipients is not always apparent in the interaction but on some occasions one of the non-medical staff asks for clarification of a medical term, such as molecular geneticist Molly in the next extract:

(2) Meeting 2: 0138-0140

\begin{tabular}{|c|c|c|}
\hline 1 & Pat: & $\begin{array}{l}\text { \{Misschien is het toch wel (.) asfyxie. } \\
\text { Perhaps it is indeed (.) asphyxia } \\
\{>\text { Cindy }\end{array}$ \\
\hline 2 & & $(1.0)$ \\
\hline 3 & Molly: & $\begin{array}{l}\text { WWat is dat } \uparrow \text { dan. } \\
\text { What is that } \uparrow \text { then. } \\
\{>\text { Pat }\end{array}$ \\
\hline 4 & Pat: & $\begin{array}{l}\text { \{zuurstofge[brek } \\
\text { oxygen deprivation }\end{array}$ \\
\hline 5 & & $\{>$ Molly \\
\hline 6 & Cindy: & $\begin{array}{l}{\left[\left\{{ }^{\circ} \text { zuurstofgebrek }{ }^{\circ}\right.\right.} \\
{ }^{\circ} \text { oxygen deprivation }{ }^{\circ}\end{array}$ \\
\hline 7 & & $\{>$ Molly \\
\hline 8 & Molly: & $\downarrow \uparrow$ \\
\hline
\end{tabular}

After Pat says to Cindy that it may be 'asphyxia', Molly asks her to clarify the term (line 3), and gets answers from two of the doctors, Pat and Cindy.
Sometimes the recipients are selected by use of medical reasoning rather than medical terminology. In the extract below, Pat offers the argument 'And then the membranes were also ruptured for a long time.' and leaves the conclusion following from that argument unsaid.

(3) Meeting 1: 30.00

\begin{tabular}{|c|c|c|}
\hline 2 & Pat: & $\begin{array}{l}\text { \{En dan waren er ook langdurig gebroken vliezen. } \\
\text { And then the membranes were also ruptured for } \\
\text { a long time. } \\
\text { \{>screen }\end{array}$ \\
\hline 3 & Mary: & $\{>$ screen $\{>$ Pat \\
\hline 4 & Mary: & $\begin{array}{l}\text { \{En wat betekent dat? } \\
\text { And what does that mean? }\end{array}$ \\
\hline 5 & Pat: & $\begin{array}{l}\text { Eeehh LANGer- a- als je de: vliezen } \\
\text { Uuuhh PROlonged- } i \text { - if you the membranes }\end{array}$ \\
\hline 6 & & $\begin{array}{l}\text { langer dan achttien uur gebroken zijn } \\
\text { are ruptured longer than eighteen hours }\end{array}$ \\
\hline 7 & & $\begin{array}{l}\text { heb je een verhoogde kans op een g- } \\
\text { you have an increased chance of a g- }\end{array}$ \\
\hline 8 & & $\begin{array}{l}\text { op een eh: groep B streptokok[ken infectie. } \\
\text { of a uh: group B streptococcus infection. }\end{array}$ \\
\hline 9 & Mary: & {$[\{\uparrow \uparrow 0::::::::$} \\
\hline 10 & & $\{>$ scherm \\
\hline 11 & Pat: & $\begin{array}{l}\text { en dan binnen vierentwintig uur op infecties. } \\
\text { and then within twenty-four hours of infections. }\end{array}$ \\
\hline 12 & Mary: & $::: h$ \\
\hline 13 & Mary: & $>$ Pat \\
\hline 14 & Mary: & $\begin{array}{l}\uparrow o k e . \\
\uparrow o k a y .\end{array}$ \\
\hline
\end{tabular}

When Pat offers her argument but the conclusion is not forthcoming, Mary stops looking at the screen on which the patient's data are projected, turns to Pat (line 3) and asks her what that means (line 4). In her answer (lines 5-8), Pat treats this question as asking not what the term 'ruptured membranes' means, but why 'ruptured membranes' are relevant, and Mary confirms this interpretation by producing a stretched news receipting 'oh' (lines 9 and 12) and a subsequent 'okay' (line 14). Interestingly, we came across only two examples of questions requesting clarification in the $210 \mathrm{~min}$ of recorded meetings, which indicates that the non-medical participants were most probably satisfied not to understand every detail.

Gaze. As we show above, a different way in which a speaker may select a recipient is by use of eye-gaze. In the extracts above we see evidence that Pat not only uses medical terminology and implicit medical reasoning but also her gaze to address fellow medical staff rather than other participants. In extract 1 , we see that Pat turns her gaze to fellow-doctor Cindy (line 5) while she talks about 'germinal haemorrhage' and that she turns her gaze to other fellow-doctor Carol (line 12) just before she uses the term 'at term newborns'.

Here we should add that Pat's turn to Carol (line 12) follows Carol's nodding response in line 10 . This shows that recipiency is not only contingent on external factors such as expertise, but may also result from acting as a recipient. Although Carol is a medical expert just as much as Cindy and Pat, Pat only starts to treat Carol as a recipient by looking at her - after Carol has acted as a recipient by nodding. 
Displaying recipiency. Carol's recipient behaviour in the above extract shows how participation frames are not only established by the speaker (through terminology, reasoning, or eye-gaze), but also by recipients by their explicit recipient behaviour (eg, through nodding).

This can also be seen in extract 4 below, in which Cindy is being addressed through the gaze of the speaker (line 20) but also Chris and Cara - both doctors - actively display their recipiency.

(4) Meeting 2: 0138-0140

\begin{tabular}{|c|c|c|}
\hline 17 & Pat: & $\begin{array}{l}\text { e::n toen hebben ze beeld\{vorming gedaan, } \\
\text { a::nd then they made a scan, }\end{array}$ \\
\hline 18 & & $\{>$ Molly \\
\hline 19 & & $\begin{array}{l}\text { en }\{\text { toen bleek 'ie een (.) hersen\{bloeding te hebben gehad } \\
\text { and then he appeared to have had a (.) brain haemorrhage }\end{array}$ \\
\hline 20 & & $\{>$ Cindy \\
\hline 21 & Cindy: & \{mouthed oh; raises hand \\
\hline 22 & Chris: & \{raises hand \\
\hline 23 & Cara: & \{raises head; > Cindy \\
\hline 24 & Pat: & $\begin{array}{l}\text { [in z'n REchter- } \quad \text { [in z'n rechter hemisfeer, } \\
\text { in the Rlght- }\end{array}$ \\
\hline 25 & Cara: & {$\left[\left(\begin{array}{llll}1 & \{\end{array}\right.\right.$} \\
\hline 26 & & \{points > Cindy; \\
\hline 27 & Cindy: & \{points $>$ Cara\{points again $>$ Cara \\
\hline 28 & & $\{\uparrow \downarrow \uparrow \downarrow \uparrow \downarrow \uparrow \downarrow$ \\
\hline
\end{tabular}

In this extract Pat is busy reporting on further developments and testing of one of the neonates when she announces that the child appeared to have had a brain haemorrhage (line 19). Cindy, Cara and Chris, all medical doctors, engage in actions that treat this information as relevant: Cindy raises her hand and opens her mouth in a silent ohsound (line 21); Chris responds by raising his hand; and Cara looks up, gazes and points at Cindy, while Cindy points at Cara (lines 26-27) and nods twice (line 28). With these responses, Chris, Cindy and Cara display themselves as recipients of the news and as participants in this activity. These responses also indicate that the medical staff treats the haemorrhage news as being particularly enlightening - or perhaps shocking - in a way that is tacitly shared and agreed upon among themselves but not disclosed to the non-medical staff.

\section{(ii) The test-results-discussion-frame}

With respect to non-medical topics, the team members present at the meeting establish different participation frames. In discussing the results of genetic lab tests, we documented several ways in which the medical staff engaged with other participants.

(5) Meeting 1: dl.2 0019-0047

\begin{tabular}{|c|c|c|}
\hline \multirow[t]{2}{*}{1} & Pat: & Ik denk dat het een combinatie \\
\hline & & I think that it has been a combination \\
\hline \multirow[t]{2}{*}{2} & & van asfyxie en convulsies is geweest \\
\hline & & of asphyxia and convulsions \\
\hline \multirow[t]{2}{*}{3} & Mary: & ${ }^{\circ} \mathrm{d}$ - dit is meer zo'n ( )fenotype ${ }^{\circ}$ \\
\hline & & ${ }^{\circ}$ t-this is more such a ()phenotype ${ }^{\circ}$ \\
\hline \multirow[t]{2}{*}{4} & Pat: & $\mathrm{Ja}=$ \\
\hline & & Yes $=$ \\
\hline \multirow[t]{2}{*}{5} & Cindy: & $=\mathrm{Ja}$ \\
\hline & & $=$ Yes \\
\hline 6 & & $(2.3)$ \\
\hline
\end{tabular}

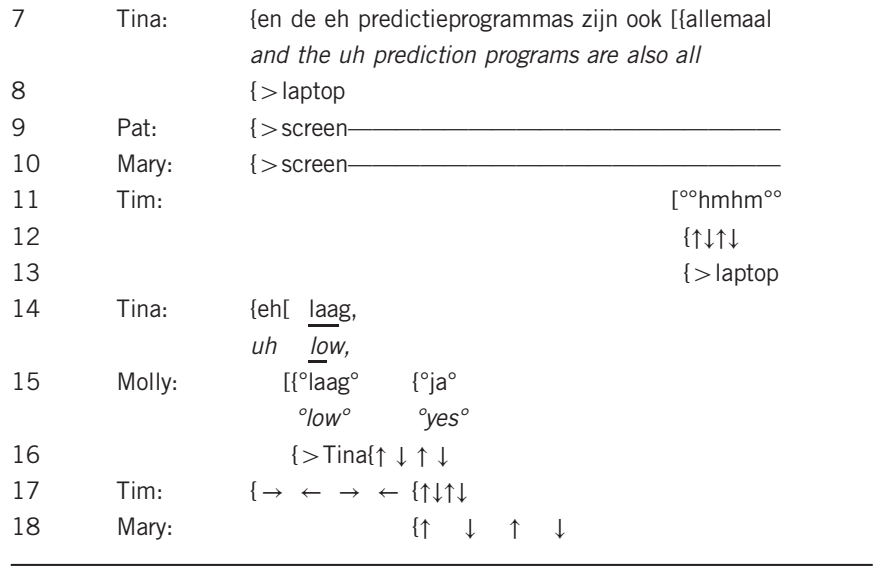

In the first lines of extract 5 (above), we see that two of the medical doctors come to a conclusion together with Mary, a biologists with a background in molecular genetics but not in medicine and who is head of the department. Pat gives her interpretation in line 1 and 2, to which Mary adds her own interpretation (line 3) and that is confirmed by two medical doctors in lines 4 and 5 . Tina, one of the genetics laboratory technicians, also presents the continuation of her report as further support of the argument given by the prior speakers with her use of 'and' (line 7). Thus, the discussion of genetic test results led to the construction of a participation frame that differed markedly from the patient discussion frame. Non-medical geneticists such as Mary, and genetic technicians such as Tina, were now seen to team up with the medical doctors in constructing common arguments and interpretations. This is further confirmed by the other participants'actions. While Tina reads the results from her computer screen (lines 7 and 14), we first see her colleague, technician Tim, confirm the report in lines $11-13$, by producing an affirmative 'hmhm' and two head nods while he looks at his laptop displaying the same data, and we also see non-medical geneticist Molly collaborate in the report by supplying the word 'low' (line 15) after Tina's hesitation ('uh') in line 14, and confirming the report verbally (line 15: 'yes') and bodily by nodding at Tina (line 16).

In terms of the participation frame, the most important question is not so much whether participants agree or disagree on reported data and their interpretation, but who is or feels called upon to display agreement and affiliation. For the discussion of test results we observed the members of this team establish a participation frame in which medical doctors, non-medical geneticists and technicians collaborated in reporting data and interpreting them, quite different from the patient discussion frame in which the medical doctors were the main protagonists.

\section{(iii) The IT-discussion-frame}

A third participation frame in this team is established for the discussion of IT issues. The project's aims are to diagnose severely ill newborns and to build a pipeline of tools to accelerate the genetic analysis process in general. Interestingly, in these discussions - in this participation frame - the medical doctors in the team were almost absent.

In excerpt 6 below for example, bio-informatician Ben selects the head of genome diagnostics Mike (molecular geneticist) as a recipient for his announcement that he has developed a particular IT tool. He does this primarily by his gaze (lines 1 and 2) and by addressing Mike 
by name (line 2), but also possibly by referring to a database that may not be familiar to all those present. In response, Mike is not the only one who displays recipiency. Both Chris (line 6), a clinical geneticist, and non-medical geneticist Molly (line 8) also shows signs of recipiency. Despite Mike being addressed by Ben, it is Chris who responded in line 16 with a positive assessment of the news. Although Chris is one of the doctors in the team, his response identifies him in this situation as responsible for development and innovation rather than as a doctor, just as Molly identifies herself here as the 5GPM project leader.

(6) Meeting 2: 1630-1820

\begin{tabular}{|c|c|c|}
\hline 1 & Ben & $>$ Mike \\
\hline 2 & Ben & $\begin{array}{l}\{>\text { maar Mike }<\text { doelde je net op die eh } \\
>\text { but Mike }<\text { did you just allude to that eh } \\
\{>\text { Mike }\end{array}$ \\
\hline 3 & & $\begin{array}{l}\text { die }>\text { database van danny macarthur }< \\
\text { that }>\text { database from danny macarthur }<\end{array}$ \\
\hline 4 & & $\begin{array}{l}\text { met die } 63\{k \text { eh }(\quad) ? \\
\text { with that } 63\{k \text { eh } \quad) ?\end{array}$ \\
\hline 5 & Mike & $\{\uparrow \downarrow$ \\
\hline 6 & Chris & $\begin{array}{l}\text { ja } \\
\text { yes }\end{array}$ \\
\hline 7 & Ben & $\begin{array}{l}\text { [tkheb }>\uparrow \text { daar ee:n tooltje voor geschreven } \\
\text { t/have }>\text { written a: tool for that }\end{array}$ \\
\hline 8 & Molly & $\begin{array}{l}\text { [ja } \\
\text { yes }\end{array}$ \\
\hline 9 & Ben & $\begin{array}{l}\text { (n) }>\text { WCS annoteert }<\text { me:t die data } \\
\text { (n) }>\text { WCS annotates }<\text { wi:th those data }\end{array}$ \\
\hline 10 & & $\begin{array}{l}>\text { of de nieuwe versie even uitspuugt }< \\
>\text { or simply spits out the new version }<\end{array}$ \\
\hline 11 & & $\begin{array}{l}\text { met een extra kolommetje. } \\
\text { with an extra column. }\end{array}$ \\
\hline 12 & & $\begin{array}{l}\text { (.) dus ik ben zelf wat annotators aan 't schrijven } \\
\text { (.) so I am writing some annotators myself }\end{array}$ \\
\hline 13 & & $\begin{array}{l}\text { voor dit soort databronnen. } \\
\text { for this type of data sources. }\end{array}$ \\
\hline 14 & Mike & $\uparrow \downarrow \uparrow \downarrow$ \\
\hline 15 & Ben & $\begin{array}{l}\text { die eh zou je hiervoor kunnen gebruiken. } \\
\text { that uh you could use for this. }\end{array}$ \\
\hline 16 & Chris & $\begin{array}{l}\text { ¡ja (da's hartstikke) (mooi) } \\
\text { oyes (that's really) (nice) }\end{array}$ \\
\hline 17 & Molly & $\begin{array}{l}\{>\text { kun je die } \mathrm{e}(\mathrm{h}) \text { ven }(\mathrm{h}) \text { aan } \mathrm{C}(\mathrm{h}) \text { arel } \mathrm{g}(\mathrm{h}) \text { even }(\mathrm{h}) ?< \\
>\text { can you share this with Bob } \\
\{>\text { Bob }\end{array}$ \\
\hline 18 & Molly & [hhh hehe\{heheh .hhh heheheh .hhh \\
\hline 19 & Tina & {$[(($ laughs $))$} \\
\hline 20 & Tracy & {$[(($ laughs $))$} \\
\hline 21 & Bob & $\begin{array}{c}{[((\text { smiles }))-((\text { laughs }))} \\
\{>\text { Molly }\end{array}$ \\
\hline 22 & Molly & $\begin{array}{l}\text { kandie in de nieuwe pi\{peline } \\
\text { then it can go into the new pipeline } \\
\qquad\{>\text { Ben }\end{array}$ \\
\hline 23 & & {$\left[\left(\begin{array}{ll}( & )\end{array}\right.\right.$} \\
\hline 24 & Ben & $\begin{array}{l}\text { [ja nee dat zou eigenlijk wel moeten ja } \\
\text { yes no that should actually have to yes }\end{array}$ \\
\hline
\end{tabular}

In terms of participation frames the joke that Molly then makes in line 17 and the responses to it are revealing. She teases another bioinformatician, Bob, by looking at him while laughingly asking Ben if he can share his tool with Bob and then produces more laughter
Table 2 Participation frames showing which disciplines took part in various topics

\begin{tabular}{lccc}
\hline & Patient discussion & Test-results discussion & IT discussion \\
\hline Clinical geneticists & $\mathrm{X}$ & $\mathrm{X}$ & \\
Molecular geneticists & & $\mathrm{X}$ & $\mathrm{X}$ \\
Neonatologists & $\mathrm{X}$ & $\mathrm{X}$ & \\
Genetical technicians & & $\mathrm{X}$ & $\mathrm{X}$ \\
Bio-informaticians & & $\mathrm{X}$ \\
\hline
\end{tabular}

(line 18). Molly thus selects Bob, be it jokingly at first, as a participant to the discussion about tools and identifies him (line 22) as someone or perhaps the person - who can insert tools into the genetic testing pipeline. From this perspective, it is also interesting that Molly's joke generates laughter only from Bob and from Tina and Tracy (lines 19, 20), who are both technicians and work with that pipeline.

Here again we see the team establishing a topic-centred and responsibility-centred participation frame in which the IT topic is discussed by bio-informaticians and those directly involved in using the tools the bio-informaticians can develop, either because they work with the pipeline or because they are responsible for it. In this participation frame, the medical doctors are conspicuously absent, with the exception of Chris who also has a responsibility for innovation of the pipeline.

\section{Resulting participation frames}

Table 2 shows the participation frames and which disciplines participate in the discussion for which topics. When discussing the patient, the participants were the clinical geneticists and the paediatricians/neonatologist with the molecular geneticists participating primarily from their positions as head of the department and project leader. In the discussion of the test results representatives of all disciplines participated with the exception of bio-informatics. Finally, the discussion of IT options was conducted by the bio-informaticians, the technicians and the molecular geneticists. One clinical geneticist participated in this, but from his position as responsible for innovation of diagnostic tools. All three discussion frames involved only a subset of the disciplines. The discussion of test results was established as the core of the 5GPM project, involving most of the disciplines.

\section{Interviews}

In order to assess the participation frames in terms of interdisciplinary quality, we presented the results of our analysis to the 5GPM team and then interviewed a selection of the participants that included representatives from all different disciplines. All interviewees assessed their interdisciplinary collaboration favourably, not only on the basis of our analysis, but also on the basis of their experience. According to these team members, the aims of the 5GPM project were well served by the division of labour that was organized spontaneously in the different participation frames. Some interviewees suggested that, since the recordings, the participation frames may have changed or been expanded to include more disciplines in each of the three discussion types. In general, they saw this as progress, although some also saw a potential risk in having participants take part in discussions outside their core-expertise, something Sims et al. ${ }^{4}$ positively referred to as 'role blurring'. The medical doctors observed that the 5GPM collaboration is very different from interdisciplinary meetings between medical professionals of different specialties. They felt that the greater 
distance between the different expertise domains within the 5GPM meetings prevented participants from claiming expertise in any other field than their own. However, all the interviewees also stated that in the course of the project they have become more knowledgeable about the other domains (Sims et al. ${ }^{4}$ called this 'individual learning'). This learning process was reported to have been established mainly in satellite meetings of small groups that were held to discuss and analyse the results for each patient before these were presented in the general team meeting.

\section{DISCUSSION}

Because NGS will have a major influence on medical diagnostic procedures worldwide, further research is needed into the work of multidisciplinary teams to establish how often such participation frames are used to solve interdisciplinary communication. Further research is also needed to show how multidisciplinary teams, as subsets or as a whole, accomplish their work processes efficiently to achieve the purpose of their meetings. In the 5GPM team, their purpose was to share information, determine a patient's diagnosis, and decide on the development of the genetic analysis pipeline and tools.

The nature of our methodology with its detailed analysis of vocal and embodied interactions does not allow us to make generalizations about interdisciplinary meetings in medical contexts. Rather, in our opinion, our study offers a view on effective interdisciplinary communication, that is informative for both communication researchers and for participants in such meetings. Our observations allow them to see interdisciplinary communication as a process in which not all participants need to be equally involved at all stages. The practical message of our study for participants in any multidisciplinary team is that spontaneously excluding some participants at some stages of the team collaboration or participants excluding themselves need not interfere with the team's goals, and may even support them. This further implies that the chairman of such meetings need not enforce adjustments to this participation frame-based communication as such enforced adjustments may even prove dysfunctional. Moreover, the methodology we have used suggests that communication researchers could start by looking at how professionals actually deal with the challenges they face, before we impose our own ideas of what interdisciplinary communication should look like.

Compared to earlier research on interdisciplinary meetings - see Bokhour ${ }^{1}$ and Youngwerth and Twaddle ${ }^{2}$ for overviews - our study has two new aspects. In terms of its methodology we took a descriptive rather than a normative or evaluative stance. Even though the aim of the study was to assess the quality of the team's communication, our Conversation-Analysis methodology focused on how participants in interdisciplinary meetings deal with the issues arising with several disciplines. In terms of our results, we have shown that successful interdisciplinary collaboration in meetings does not imply that all the participants have access to all communication processes, nor will they participate in all of them. Rather than having established one language-for-all or a 'collective communicative competence', ${ }^{6}$ the 5GPM team has been shown to work with different participation frames for different communicative purposes, related to differences in disciplines and institutional responsibility, which arose ad hoc and which were somewhat fluid.

\section{CONCLUSION}

Extensive interdisciplinary collaboration for NGS includes the task of dealing with communication differences between the various disciplines and groups or individuals who have not physically collaborated before. The 5GPM project at UMCG needed to establish a multidisciplinary collaboration between clinical geneticists, paediatricians, molecular geneticists, technicians and bio-informaticians. Their question was: 'How do we manage to communicate across our interdisciplinary differences?'.

To answer this question we made video recordings of seven consecutive 1-h meetings held weekly from October to December 2014 and analysed these videos to study how the team communicated. This led to a mixed picture of a team that both does and does not communicate across disciplinary boundaries. Instead of having developed a mode of communication in which all different disciplines can participate, the team appeared to have developed, and continued to establish, different participation frames for discussing different topics.

Our analysis shows that these participation frames are, on the one hand, relatively stable, while, on the other hand, they are emergent categories in the sense that they are composed ad hoc in the context of the team's meetings. The participation frames do not exist prior to the interaction which implies that they can also change over time. As we have seen, the participants were established by the actions of both the speakers and the listeners.

Participation appeared to be organized with an orientation to expertise and responsibility. In terms of expertise, we saw that the medical doctors made no effort to include those who were not medical doctors, neither in their choice of addressees, nor in use of vocabulary or reasoning. Although it should be added that the non-medical team members might not have been able to discuss phenotypes, treatment or diagnosis, not in terms of their expertise, nor of their responsibilities. In the same manner, the absence of medical doctors taking part in the IT discussion on aspects of the genetic analyses pipeline reflected not only the use of technical jargon by the bio-informaticians and the medical doctors' lack of expertise in this field, but also the fact that the pipeline was not their responsibility. From this perspective, it should not be a surprise that the participation frame with the most participating disciplines was organized around the topic at the core of the team's activities and shared responsibility: genetic testing and data interpretation.

\section{CONFLICT OF INTEREST}

The authors declare no conflict of interest.

1 Bokhour BG: Communication in interdisciplinary team meetings: what are we talking about? J Interprof Care 2006; 20: 349-363.

2 Youngwerth J, Twaddle M: Cultures of interdisciplinary teams: how to foster good dynamics. J Palliat Med 2011; 14: 650-654.

3 Allen JA, Lehmann-Willenbrock N, Rogelberg SG (eds): The Cambridge Handbook of Meeting Science. Cambridge, UK: Cambridge University Press, 2015.

4 Sims S, Hewitt G, Harris R: Evidence of collaboration, pooling of resources, learning and role blurring in interprofessional healthcare teams: a realist synthesis. $J$ Interprof Care 2015; 29: 20-25.

5 Nancarrow SA, Smith T, Ariss S, Enderby PM: Qualitative evaluation of the implementation of the interdisciplinary management tool: a reflective tool to enhance interdisciplinary teamwork using structured, facilitated action research for implementation. Health Social Care Community 2015; 23: 437-448.

6 Thompson JL: Building collective communication competence in interdisciplinary research teams. J App/ Commun Res 2009; 37: 278-297.

7 Raclaw J, Ford CE: Meetings as interactional achievements, a conversation analytic perspective; in Allen JA, Lehmann-Willenbrock N, Rogelberg SG (eds): The Cambridge Handbook of Meeting Science. Cambridge, UK: Cambridge University Press, 2015, pp 247-276.

8 Goffman E: Frame Analysis. An Essay on the Organization of Experience. Boston, MA, USA: Northeastern University Press, 1974.

9 Goffman E: Forms of Talk. Philadelphia, PA: University of Pennsylvania Press, 1981

10 Asmuß B: Multimodal perspectives on meeting interaction: recent trends in conversation analysis; in Allen JA, Lehmann-Willenbrock N, Rogelberg SG (eds): The Cambridge Handbook of Meeting Science. Cambridge, UK: Cambridge University Press, 2015, pp 277-304. 
11 Goodwin C: The interactive construction of a sentence in natural conversation; in Psathas G (ed): Everyday Language: Studies in Ethnomethodology. New York, NY, USA: Irvington Publishers, 1979, pp 97-121.

12 Goodwin C: Conversational Organization: Interaction between Speakers and Hearers. New York, NY, USA: Academic Press, 1981.

13 Goodwin C: Notes on story structure and the organization of participation; in Atkinson JM, Heritage J (eds). Structures of social action. Cambridge, UK: Cambridge University Press, 1984, pp 225-246.

14 Jefferson G: Transcript notation; in Atkinson JM, Heritage J (eds). Structures of Social Action. Studies in Conversation Analysis. Cambridge, UK: Cambridge University Press, 1984, pp ix-xvi.
15 Sidnell J, Stivers T (eds): The Handbook of Conversation Analysis. Oxford, UK: WileyBlackwell, 2013.

16 Levinson S: Action formation and ascription; in Sidnell J, Stivers T (eds). The Handbook of Conversation Analysis. Oxford, UK: Wiley-Blackwell, 2013, pp 103-130.

17 Sacks H, Schegloff E, Jefferson G: A simplest systematics for the organization of turntaking for conversation. Language 1974; 50: 696-735.

18 Huiskes M: The role of the clause for turn-taking in Dutch conversations. Utrecht, The Netherlands: LOT, 2010.

19 Schegloff EA: Sequence Organization in Interaction. Cambridge, UK: Cambridge University Press, 2007.

20 ten Have P: Doing Conversation Analysis. A Practical Guide. London, UK: Sage, 1999. 